\title{
ANALISIS DETERMINAN KUALITAS LAPORAN KEUANGAN LEMBAGA PERKREDITAN DESA (LPD) DI KOTA DENPASAR
}

\author{
Ni Putu Shinta Dewi \\ Universitas Mahasaraswati Denpasar \\ shintaniputu@gmail.com \\ Ni Putu Lisa Ernawatiningsih \\ Universitas Mahasaraswati Denpasar \\ ernawatiningsih.lisa@gmail.com
}

\begin{abstract}
The aim of the study was to obtain empirical evidence on the influence of the level of understanding of accounting, the function of the internal supervisory body, the quality of accounting information systems, the quality of human resources on the quality of village credit institutions (LPD) financial statements in Denpasar City. The data analysis technique used is multiple linear regression analysis. The results of the analysis show the level of understanding of accounting, the functions of the internal supervisory body, and the quality of human resources have a positive effect on the quality of LPD financial statements in Denpasar City. While the quality of accounting information systems does not affect the quality of LPD financial statements in Denpasar City.
\end{abstract}

Keywords: level of understanding of accounting, functions of internal supervisory bodies, quality of accounting information systems, quality of human resources on the quality of financial statements, LPD

\section{I.PENDAHULUA N}

Salah satu bentuk pertanggungjawaban suatu organisasi profit adalah penyusunan laporan keuangan. Proses penyusunan laporan keuangan tidak luput dari berbagai pertimbangan, hal ini dilakukan agar laporan keuangan yang disajikan dapat terlihat lebih baik dan berkualitas. Kualitas laporan keuangan adalah sejauh mana laporan keuangan yang disajikan menunjukan informasi yang benar dan jujur. Kualitas laporan keuangan berguna sebagai dasar pengambilan keputusan ekonomi bagi pihak yang berkepentingan. Kualitas laporan keuangan dengan berbagai pengukurannya, umumnya digunakan dalam keputusan investasi, perjanjian kompensasi dan persyaratan hutang, keputusan kontrak yang berdasarkan kualitas laporan keuangan yang rendah akan mempengaruhi transfer kesejahteraan yang tidak diinginkan (Rosdiani, 2011). Permasalahan mengenai kualitas laporan keuangan kini semakin hangat di perbincangkan, banyaknya kasus-kasus buruknya kualitas laporan keuangan pada perusahaan maupun pemerintah daerah di Indonesia masih menjadi isu hangat yang perlu dikaji lebih dalam. Hal ini disebabkan oleh kurangnya pemahaman Standar Akuntansi Keuangan dalam penyusunan Laporan keuangan tersebut. 
Sistem Informasi Akuntansi (SIA) membantu dalam pengolahan data untuk menghasilkan informasi yang akurat dan tepat waktu sehingga dapat menjadi nilai tambah bagi suatu perusahaan. SIA sangat terkait dengan pemanfaatan teknologi informasi dan aplikasinya dilakukan dengan komputer. Pemanfaatan sistem informasi berbasis komputer sebagai salah satu bentuk teknologi informasi telah mengubah pengolahan data akuntansi dari manual menjadi otomatis (Hidayati, 2016).

Banyak perusahaan melakukan investigasi pada teknologi informasi dengan harapan dapat memberikan keunggulan kompetitif. Dampak teknologi informasi terhadap kinerja organisasi telah menjadi perdebatan. Pertanyaan yang sering diajukan apakah penggunaan teknologi informasi dalam sebuah perusahaan didukung dengan keahlian sumber daya manusianya. Seringkali perusahaan telah menggunakan teknologi informasi yang canggih atau mutakhir tetapi pengguna tidak dapat mengoperasikan teknologi yang sudah ada. Dalam hal ini sumber daya manusia merupakan personel yang paling penting dalam suatu perusahaan atau organisasi karena pada kenyataannya manusia merupakan elemen yang selalu ada dalam setiap organisasi (Dewi,2017).

Pengembangan sistem informasi merupakan sebuah keputusan yang sangat strategis. Selain menyangkut investigasi yang cukup besar, terdapat banyak faktor lain yang harus dipertimbangkan. Sistem informasi harus dikembangkan untuk memenuhi kebutuhan dan keinginan pengguna, karena dalam pengembangan sistem informasi akuntansi, faktor manusia sangat menentukan dalam keberhasilan penerapan sistem informasi tersebut. Sebaik apapun sistem yang telah dirancang, tetapi jika penggunanya tidak mau melaksanakannya maka akan sia-sialah sistem tersebut (Dewi,2017). Disamping itu dalam mencapai keunggulan kompetitif, hal penting yang harus diperhatikan adalah keberhasilan sistem yang diterapkan di perusahaan. Keberhasilan sistem dapat dicapai dengan memperhatikan hal-hal dalam penggunaan komputer sebagai alat pengolah data yaitu risiko-risiko yang muncul dalam suatu lingkungan akuntansi yang menggunakan komputer. Risiko merupakan fungsi dari kemungkinan adanya ancaman dari sumber yang ada yang menyebabkan kerugian perusahaan (Wiartama, 2015).

Risiko dalam pemrosesan data adalah kesalahan-kesalahan yang terjadi karena perilaku manusianya sendiri, baik kesalahan yang disengaja maupun kesalahan yang tidak disengaja. Kesalahan yang disengaja dapat berbentuk kecurangan atau penyelewengan kekayaan perusahaan yang dilakukan oleh seseorang di luar petugas yang bertanggung jawab atau oleh karyawan sendiri yang dipercaya untuk menjaga keamanan kekayaan milik perusahaan. Dengan adanya risiko tersebut maka penaksiran risiko sangat diperlukan. Dengan penaksiran risiko maka dapat segera dilakukan pengendalian dalam sistem informasi akuntansi. Pengendalian ini bertujuan untuk menghasilkan informasi yang dapat dipercaya dan akan bermanfaat untuk pengembangan perusahaan ke arah yang lebih baik.

Beberapa penelitian menjabarkan faktor-faktor yang mempengaruhi kualitas laporan keuangan, penelitian Yuliani (2010) pada pemerintahan kota Banda Aceh bahwa pemahaman akuntansi, pemanfaatan sistem informasi akuntansi keuangan daerah dan peran internal audit berpengaruh positif terhadap kualitas laporan keuangan pemerintah daerah. Hasil penelitian yang dilakukan oleh Fikri (2011), yang meneliti mengenai penerapan sistem informasi keuangan daerah pada instansi pemerintah Kota Padang, dia menyatakan bahwa sistem informasi keuangan daerah berpengaruh signifikan positif terhadap kualitas laporan keuangan pemerintah daerah. Penelitian Roviyantie (2011) tentang pengaruh kompetensi sumber daya manusia dan penerapan sistem akuntansi keuangan daerah berpengaruh positif terhadap kualitas laporan keuangan daerah pada organisasi perangkat daerah di Kabupaten Tasikmalaya.

Berdasarkan penjelasan di atas, maka penulis tertarik untuk melakukan penelitian lebih lanjut, berjudul "Analisis Determinan Kualitas Laporan Keuangan Lembaga Perkreditan Desa (LPD) di Kota Denpasar ".Berdasarkan latar belakang masalah yang telah disampaikan di atas, maka rumusan permasalahan dalam penelitian ini adalah: 1) Bagaimana pengaruh tingkat 
pemahaman akuntansi terhadap kualitas laporan keuangan pada LPD di Kota Denpasar? 2) Bagaimana pengaruh fungsi badan pengawas internal terhadap kualitas laporan keuangan pada LPD di Kota Denpasar? 3) Bagaimana pengaruh kualitas sistem informasi akuntansi terhadap kualitas laporan keuangan pada LPD di Kota Denpasar? 4) Bagaimana pengaruh kualitas sistem informasi akuntansi terhadap kualitas laporan keuangan pada LPD di Kota Denpasar

Berdasarkan latar belakang dan pokok permasalahan yang telah disampaikan, maka tujuan dari penelitian ini adalah untuk mengetahui pengaruh tingkat pemahaman akuntansi, pengaruh fungsi badan pengawas internal, pengaruh kualitas sistem informasi akuntansi dan pengaruh kualitas sumber daya manusia terhadap kualitas pelaporan keuangan.

\section{LANDASAN TEORI}

\section{Technology Acceptance Model (TAM)}

Menurut Jogiyanto (2017) Technologi Acceptance Model (TAM) adalah sebuah teori yang dirancang untuk menjelaskan bagaimana pengguna mengerti dan menggunakan sebuah teknologi informasi. Menurut Davis, et al. (1989), tujuan dasar dari TAM adalah untuk memberikan penjelasan tentang faktor apa saja yang menentukan penerimaan teknologi yang mampu menjelaskan perilaku penggunanya. Teori ini menyediakan suatu basis teoritis untuk mengetahui faktor-faktor yang mempengaruhi penerimaan terhadap suatu teknologi dalam suatu organisasi, sehingga mampu menjelaskan hubungan sebab akibat antara keyakinan (akan manfaat suatu sistem informasi dan kemudahan penggunanya) dan perilaku, tujuan/keperluan dan penggunaan aktual dari pengguna suatu sistem informasi. Teori TAM dirasa memiliki hubungan dengan faktor-faktor yang mempengaruhi kinerja sistem informasi akuntansi dimana faktor keterlibatan pemakai, kecanggihan teknologi informasi, partisipasi manajemen, pengetahuan manajer akuntansi termasuk kedalam konsep kedua yaitu persepsi pemanfaatan (perceived usefulness) yang ada dalam teori TAM. Konsep ini menggambarkan manfaat sistem bagi penggunanya yang berkaitan dengan produktivitas, kinerja tugas, efektivitas, dan pentingnya suatu tugas sehingga empat faktor tersebut dapat mendukung efektivitas penggunaan SIA

\section{Kualitas Laporan Keuangan}

Menurut Komite Standar Akuntansi Pemerintah (2005 : KK-10) karakteristik kualitatif laporan keuangan adalah ukuran-ukuran normatif yang perlu diwujudkan dalam informasi akuntansi agar dapat memenuhi tujuannya. Prasyarat normatif yang diperlukan agar laporan keuangan pemerintah dapat memenuhi kualitas yang dikehendaki yaitu relevan, andal, dapat dibandingkan dan dapat dipahami.

\section{Tingkat Pemahaman Akuntansi}

Menurut Peraturan Pemerintah Nomor 24 Tahun 2005 tentang Standar Akuntansi Pemerintahan pasal 1 menyebutkan bahwa akuntansi adalah proses pencatatan, pengukuran, pengklasifikasian, pengikhtisaran transaksi dan kejadian keuangan, pengintrepretasian atas hasilnya serta penyajian laporan. Standar Akuntansi Pemerintah (SAP) adalah prinsip-prinsip akuntansi yang diterapkan dalam menyusun dan menyajikan laporan keuangan pemerintah. Paham menurut Kamus Umum Bahasa Indonesia (Poerwadarminta : 2006) mempunyai pengertian pandai dan mengerti benar sedangkan pemahaman adalah proses, cara, perbuatan memahami atau memahamkan. Ini berarti bahwa orang yang memiliki pemahaman akuntansi adalah orang yang pandai dan mengerti benar tentang akuntansi. Seseorang dikatakan paham terhadap akuntansi adalah mengerti dan pandai bagaimana proses akuntansi itu dilakukan sampai menjadi suatu laporan keuangan dengan berpedoman pada prinsip dan standar 
penyusunan laporan keuangan yang ditetapkan dalam Peraturan Pemerintah Nomor 24 Tahun 2005 tentang Standar Akuntansi Pemerintahan.

Berdasarkan penelitian Yuliani (2010) dan Diani (2014) menyatakan bahwa tingkat pemahaman akuntansi berpengaruh positif terhadap kualitas laporan keuangan. Penelitian yang dilakukan oleh Aniftahudin (2016) juga menyatakan ba,hwa tingkat pemahaman akuntansi berpengaruh positif terhadap kualitas laporan keuangan maka hipotesis dalam penelitian ini yaitu:

$\mathrm{H}_{1}$ : Tingkat pemahaman akuntansi berpengaruh positif terhadap kualitas laporan keuangan pada LPD di Kota Denpasar.

\section{Fungsi Badan Pengawas Internal}

Pengawasan adalah suatu upaya yang sistematik untuk menetapkan kinerja standar pada perencanaan untuk merancang sistem umpan balik informasi, untuk membandingkan kinerja aktual dengan standar yang telah ditentukan, untuk menetapkan apakah telah terjadi suatu penyimpangan tersebut, serta untuk mengambil tindakan perbaikan yang diperlukan untuk menjamin bahwa semua sumber daya perusahaan atau pemerintahan telah digunakan seefektif dan seefisien mungkin guna mencapai tujuan perusahaan atau pemerintahan.

Berdasarkan penelitian Putra dan Gunadi (2017) dan penelitian yang dilakukan Yenita (2010) menyatakan bahwa fungsi badan pengawas internal berpengaruh positif terhadap kualitas laporan keuangan. Penelitian yang dilakukan oleh Sukirman \& Nurhasan (2013) berpendapat bahwa dukungan badan pengawas internal berpengaruh secara positif terhadap kualitas laporan keuangan, maka hipotesis dalam penelitian ini yaitu:

$\mathrm{H}_{2}$ : Fungsi badan pengawas internal berpengaruh positif terhadap kualitas laporan keuangan pada LPD di Kota Denpasar.

\section{Kualitas Sistem Informasi Akuntansi}

Sistem Informasi akuntansi suatu organisasi memainkan peranan yang sangat penting dalam membantu organisasi untuk mengadopsi dan mempertahankan posisi strateginya. Mencapai kesesuaian yang baik antar aktivitas membutuhkan pengumpulan data tiap aktivitas. Bagi Suatu perusahaan, sistem informasi akuntansi dibangun dengan tujuan utama untuk menglah data akuntansi yang berasal dari berbagai sumber menjadi informasi akuntansi yang diperlukan oleh berbagai macam pemakai untuk mengurangi resiko saat mengambil keputusan. Sehingga kualitas sistem informasi akuntansi sangat penting dalam menunjang kualitas laporan keuangan Susanto (2013:10).

Berdasarkan penelitian Astuti (2012), Tawaqal dan Suparno (2017) menyatakan bahwa kualitas sistem informasi akuntansi berpengaruh positif terhadap kualitas laporan keuangan, maka hipotesis dalam penelitian ini yaitu:

$\mathrm{H}_{3}$ : Kualitas sistem informasi akuntansi berpengaruh positif terhadap kualitas laporan keuangan pada LPD di Kota Denpasar.

\section{Kualitas Sumber Daya Manusia}

Kualitas sumber daya manusia adalah kemampuan seseorang atau individu, suatu organisasi/kelembagaan, atau suatu sistem untuk melaksanakan fungsi-fungsi atau kewenangannya untuk mencapai tujuannya secara efektif dan efisien. Kemampuan sumber daya manusia menurut Robbins (2006 : 52) diartikan sebagai kapasitas individu untuk mengerjakan berbagai tugas dalam pekerjaan tertentu. Kemampuan keseluruhan seseorang pada hakikatnya terdiri dari dua faktor, yaitu kemampuan intelektual dan kemampuan fisik. Dalam pekerjaan terkait kegiatan administrasi pada suatu organisasi, kemampuan intelektual tentu lebih dominan. Kemampuan intelektual seseorang dalam menyelesaikan pekerjaan tertentu bersumber dari latar belakang pendidikan dan pengalaman yang dimilikinya.

Berdasarkan penelitian Lasmara dan Rahayu (2016) dan penelitian Evicahyani (2015) menyatakan bahwa kualitas sumber daya manusia berpengaruh positif terhadap kualitas laporan keuangan, maka hipotesis dalam penelitian ini yaitu: 
$\mathrm{H}_{4}$ : Kualitas sumber daya manusia berpengaruh positif terhadap kualitas laporan keuangan pada LPD di Kota Denpasar.

\section{METODOLOGI PENELITIAN}

\section{Jenis Data}

Berdasarkan jenisnya (Sugiyono, 2017:9), data dapat dibagi menjadi dua yaitu sebagai berikut:

1) Data kualitatif adalah data yang dinyatakan dalam bentuk kata, kalimat, dan skema. Data kualitatif dalam penelitian ini berupa sejarah, struktur organisasi secara umum, dan data kepegawaian dari LPD di Kota Denpasar.

2) Data kuantitatif adalah data dalam bentuk angka yang dapat dinyatakan dan diukur dengan satuan hitung atau data kualitatif yang diangkakan. Dalam penelitian ini data kuantitatif yang diperoleh berupa hasil dari pengukuran variabel yang digunakan.

\section{Sumber Data}

Berdasarkan sumbernya (Sugiyono, 2017:11), data primer adalah sumber data yang langsung memberikan data kepada pengumpul data. Data yang dimaksud adalah jawaban-jawaban yang diberikan oleh responden atas pernyataan-pernyataan dalam kuesioner yang berhubungan dengan penelitian.

\section{Populasi dan Sampel}

Menurut Sugiyono (2017:136) populasi adalah wilayah generalisasi yang terdiri atas objek atau subjek yang mempunyai kualitas dan karakteristik tertentu yang ditetapkan oleh peneliti untuk dipelajari dan kemudian ditarik kesimpulannya. Populasi dalam penelitian ini adalah seluruh karyawan yang bekerja pada LPD di Kota Denpasar yang berjumlah 105 orang

\section{Sampel}

Sampel adalah sebagian kecil dari populasi yang karakteristiknya hendak diselidiki, Sugiyono (2017:137). Metode penentuan sampel yang digunakan dalam penelitian ini adalah dengan menggunakan teknik non probability sampling. Teknik non probability sampling adalah teknik pengambilan sampel yang tidak berpeluang atau tidak memiliki kesempatan yang sama bagi unsur atau anggota populasi untuk dipilih menjadi sampel. Teknik non probability sampling yang digunakan dalam penelitian ini adalah purposive sampling, yaitu penentuan sampel dengan menggunakan pertimbangan atau kriteria tertentu Sugiyono (2017:144). Pengambilan sampel secara tidak acak yang didasarkan pada kriteria-kriteria tertentu sesuai dengan yang telah ditetapkan oleh peneliti. Kriteria pengambilan sampel dalam penelitian ini yaitu: karyawan yang bekerja pada LPD di Kota Denpasar dan karyawan yang menggunakan SIA.

\section{Metode Pengumpulan Data}

1) Kuesioner

Merupakan teknik pengumpulan data yang dilakukan dengan cara memberi seperangkat pertanyaan atau pernyataan tertulis kepada responden untuk dijawabnya (Sugiyono, 2017:225). Kuesioner yang disebarkan berupa daftar pertanyaan atau pernyataan tertulis kepada responden.

2)Dokumentasi

Merupakan teknik pengumpulan data dimana peneliti menyelidiki benda-benda tertulis seperti buku-buku, majalah, dokumen, peraturan-peraturan, dan sebagainya (Wiartama, 2015). Metode ini digunakan untuk memperoleh data tentang sejarah, struktur organisasi secara umum, dan data kepegawaian dari LPD di Kota Denpasar. 


\section{Teknik Analisis Data \\ 1.Uji Validitas}

Uji validitas digunakan untuk mengukur sah atau valid tidaknya suatu kuesioner. Suatu kuesioner dikatakan valid jika pertanyaan pada kuesioner tersebut mampu mengungkapkan sesuatu yang akan diukur oleh kuesioner tersebut (Ghozali, 2016:52). Uji validitas dalam penelitian ini dilakukan melalui perhitungan koefisien korelasi (Pearson Correlation). Instrumen dinyatakan valid apabila hasil perhitungan koefisien korelasi menunjukan koefisien korelasi sebesar 0,3 atau lebih (Sugiyono, 2017:178).

\section{Uji Reliabilitas}

Reliabilitas adalah alat untuk mengukur suatu kuesioner yang merupakan indikator dari variabel atau konstruk. Suatu kuesioner dikatakan reliabel atau handal jika jawaban seseorang terhadap pernyataan adalah konsisten atau stabil dari waktu ke waktu (Ghozali, 2016:47). Untuk mengukur reliabilitas digunakan uji statistik Cronbach Alpha. Suatu variabel dikatakan reliabel jika memberikan nilai Cronbach Alpha> 0,70 (Ghozali, 2016:48)

\section{Statistik Deskriptif}

Statistik deskriptif menurut Ghozali (2016: 19) merupakan gambaran atau deskripsi suatu data yang dilihat dari nilai rata-rata (mean), standar deviasi, varian, maksimum, minimum, sum, range, kurtosis dan skewness (kemencengan distribusi).

\section{Uji Asumsi Klasik}

Uji asumsi klasik yang digunakan dalam penelitian ini adalah :

1.Uji Normalitas

2.Uji Multikolinearitas

3.Uji Autokorelasi

4.Uji Heterokedastisitas

\section{Analisis Regresi Linier Berganda}

Analisi regresi merupakan alat untuk mengukur bagaimana pengaruh dari veriabel independen terhadap variabel dependen dalam penelitian. Analisis regresi linier berganda akan dilakukan bila jumlah variabel bebasnya minimal dua. Rumus regresinya adalah :

$\mathrm{Y}=\alpha+\beta_{1}$ TPA $+\beta_{2}$ FBPI $+\beta_{3}$ KSIA $+\beta_{4}$ KSDM + e.

Keterangan :

Y

$\alpha$

$\beta_{\mathrm{i}}$

TPA

FBPI

KSIA

KSDM

e

\section{Uji Kelayakan Model (Goodness of Fit Model)}

\section{1) Koefisien Determinasi}

Menurut Ghozali (2016:95), kelemahan mendasar penggunaan koefisien determinasi adalah bias terhadap jumlah variabel independen yang dimasukkan ke dalam model. Setiap tambahan satu variabel independen, maka $\mathrm{R}^{2}$ pasti meningkat tidak perduli apakah variabel tersebut berpengaruh secara signifikan terhadap veriabel dependen.

2) Uji Statistik $F$

Uji F merupakan uji signifikansi secara keseluruhan terhadap garis regresi yang diobservasi maupun estimasi, apakah variabel dependen berhubungan linier terhadap seluruh variabel independen (Ghozali, 2016:96). Tingkat signifikan uji $\mathrm{F}$ adalah 0,05, untuk menguji kebenaran koefisien regresi secara keseluruhan. Pengambilan keputusan dengan uji $\mathrm{F}$ adalah : 
a. Jika sig > 0,05 maka tidak ada pengaruh secara serempak variabel bebas $(\mathrm{X})$ terhadap variabel terikat $(\mathrm{Y})$.

b. Jika sig $\leq 0,05$ maka ada pengaruh secara serempak variabel bebas $(\mathrm{X})$ terhadap variabel terikat $(\mathrm{Y})$.

3) Uji-t

Menurut Ghozali (2016:97), uji statistik t pada dasarnya menunjukkan seberapa jauh pengaruh satu variabel penjelas/independen secara individual dalam menerangkan variasi variabel dependen. Uji-t dapat dilakukan dengan tingkat signifikansi 0,05. Apabila nilai t-hitung positif maka variabel independen berpengaruh positif terhadap variabel dependen. Keputusan yang dapat diambil dengan uji-t dapat menggunakan cara berikut ini :

a. Jika sig > 0,05 maka tidak ada pengaruh secara parsial variabel bebas $(\mathrm{X})$ terhadap variabel terikat $(\mathrm{Y})$.

b. Jika sig $\leq 0,05$ maka ada pengaruh secara parsial variabel bebas $(\mathrm{X})$ terhadap variabel terikat.

\section{HASIL PENELITIAN}

4.1 Uji Validitas dan Reliabilitas

Tabel 4.1 Uji Validitas

\begin{tabular}{|c|c|c|c|c|}
\hline No. & Variabel & Pertanyaan & $\begin{array}{c}\text { Pearson } \\
\text { Correlation }\end{array}$ & Keterangan \\
\hline \multirow[t]{5}{*}{1} & \multirow{5}{*}{$\begin{array}{l}\text { Tingkat Pemahaman } \\
\text { Akuntansi }\left(\mathrm{X}_{1}\right)\end{array}$} & $\mathrm{X} 1.1$ & 0,653 & Valid \\
\hline & & $\mathrm{X} 1.2$ & 0,786 & Valid \\
\hline & & $\mathrm{X} 1.3$ & 0,755 & Valid \\
\hline & & X1.4 & 0,803 & Valid \\
\hline & & $\mathrm{X} 1.5$ & 0,783 & Valid \\
\hline \multirow[t]{4}{*}{2} & \multirow{4}{*}{$\begin{array}{l}\text { Fungsi Badan Pengawas } \\
\text { Internal }\left(\mathrm{X}_{2}\right)\end{array}$} & $\mathrm{X} 2.1$ & 0,768 & Valid \\
\hline & & $\mathrm{X} 2.2$ & 0,827 & Valid \\
\hline & & $\mathrm{X} 2.3$ & 0,829 & Valid \\
\hline & & $\mathrm{X} 2.4$ & 0,912 & Valid \\
\hline \multirow[t]{8}{*}{3} & \multirow{8}{*}{$\begin{array}{l}\text { Kualitas Sistem Informasi } \\
\text { Akuntansi }\left(\mathrm{X}_{3}\right)\end{array}$} & $\mathrm{X} 3.1$ & 0,691 & Valid \\
\hline & & X3.2 & 0,484 & Valid \\
\hline & & $\mathrm{X} 3.3$ & 0,572 & Valid \\
\hline & & X3.4 & 0,789 & Valid \\
\hline & & $\mathrm{X} 3.5$ & 0,565 & Valid \\
\hline & & X3.6 & 0,738 & Valid \\
\hline & & X3.7 & 0,709 & Valid \\
\hline & & X3.8 & $-0,007$ & TidakValid \\
\hline \multirow[t]{8}{*}{4} & \multirow[t]{8}{*}{ Kualitas SDM $\left(\mathrm{X}_{4}\right)$} & $\mathrm{X} 4.1$ & 0,619 & Valid \\
\hline & & $\mathrm{X} 4.2$ & 0,648 & Valid \\
\hline & & $\mathrm{X} 4.3$ & 0,680 & Valid \\
\hline & & $\mathrm{X} 4.4$ & 0,680 & Valid \\
\hline & & $\mathrm{X} 4.5$ & 0,462 & Valid \\
\hline & & $\mathrm{X} 4.6$ & 0,667 & Valid \\
\hline & & $\mathrm{X} 4.7$ & 0,692 & Valid \\
\hline & & $\mathrm{X} 4.8$ & 0,803 & Valid \\
\hline \multirow[t]{2}{*}{5} & \multirow{2}{*}{$\begin{array}{l}\text { Kualitas Pelaporan } \\
\text { Keuangan (Y) }\end{array}$} & Y.1 & 0,749 & Valid \\
\hline & & Y.2 & 0,719 & Valid \\
\hline
\end{tabular}




\begin{tabular}{|l|c|c|c|c|}
\hline \multirow{3}{*}{} & Y.3 & 0,769 & Valid \\
\cline { 2 - 4 } & Y.4 & 0,715 & Valid \\
\cline { 2 - 4 } & Y.5 & 0,507 & Valid \\
\hline
\end{tabular}

Sumber : Hasil olah data

Berdasarkan Tabel diatas menunkjukkan bahwa ada satu butir pertanyaan yang tidak valid karena nilai pear correlation kurang dari 0,3 yaitu butir pertanyaan 8 untuk variabel bebas $X_{3}$, sedangkan sisanya semua item pertanyaan valid untuk variabel bebas $X_{1}, X_{2}, X_{4}$, dan variabel Y karena nilai pear correlationnya lebih besar dari 0,3.

Tabel 4.2 Uji Reliabilitas

\begin{tabular}{|c|l|c|c|}
\hline No. & \multicolumn{1}{|c|}{ Variabel } & $\begin{array}{c}\text { Nilai Cronbach } \\
\text { Alpha }\end{array}$ & Keterangan \\
\hline 1 & Tingkat Pemahaman Akuntansi $\left(\mathrm{X}_{1}\right)$ & 0,813 & Reliabel \\
\hline 2 & Fungsi Badan Pengawas Internal $\left(\mathrm{X}_{2}\right)$ & 0,850 & Reliabel \\
\hline 3 & Kualitas Sistem Informasi Akuntansi $\left(\mathrm{X}_{3}\right)$ & 0,773 & Reliabel \\
\hline 4 & Kualitas SDM $\left(\mathrm{X}_{4}\right)$ & 0,809 & Reliabel \\
\hline 5 & Kualitas Pelaporan Keuangan $(\mathrm{Y})$ & 0,723 & Reliabel \\
\hline
\end{tabular}

Sumber: Hasil olah data

Berdasarkan Tabel diatas menunjukkan semua variabel memiliki nilai Cronbach alpha diatas 0,6 sehingga seluruh variabel reliabel.

\section{Uji Statistik Deskriptif}

Tabel Statistik Deskriptif

\begin{tabular}{|l|r|r|r|r|r|}
\hline & N & \multicolumn{1}{|c|}{ Minimum } & Maximum & \multicolumn{1}{c|}{ Mean } & Std. Deviation \\
\hline X1 & 105 & 14.00 & 25.00 & 22.0476 & 2.33445 \\
X2 & 105 & 12.00 & 20.00 & 17.0857 & 1.62974 \\
X3 & 105 & 23.00 & 35.00 & 29.8952 & 2.47263 \\
X4 & 105 & 26.00 & 40.00 & 34.4571 & 3.00329 \\
Y & 105 & 19.00 & 25.00 & 21.9429 & 1.88020 \\
Valid N & 105 & & & & \\
(listwise) & & & & \\
\hline
\end{tabular}

Berdasarkan Tabel diatas diperoleh hasil sebagai berikut:

a. Untuk variabel $\mathrm{X}_{1}$ nilai mean sebesar 22,0476 dan standar deviasi sebesar 2,33445

b. Untuk variabel $\mathrm{X}_{2}$ nilai mean sebesar 17,0857 dan standar deviasi sebesar 1,62974

c. Untuk variabel $\mathrm{X}_{3}$ nilai mean sebesar 29,8952 dan standar deviasi sebesar 2,47263

d. Untuk variabel $\mathrm{X}_{4}$ nilai mean sebesar 34,4571 dan standar deviasi sebesar 3,00329

e. Untuk variabel Y nilai mean sebesar 21,9429 dan standar deviasi sebesar 1,88020

\subsection{Hasil Uji Asumsi Klasik}

1) Uji Normalitas

Tabel Uji Normalitas

\begin{tabular}{|lc|r|}
\hline & $\begin{array}{c}\text { Unstandardize } \\
\text { d Residual }\end{array}$ \\
\hline $\begin{array}{l}\mathrm{N} \\
\text { Normal Parameters }{ }^{\mathrm{a}, \mathrm{b}} \quad \text { Mean }\end{array}$ & $\begin{array}{r}105 \\
.0000000\end{array}$ \\
\hline
\end{tabular}




\begin{tabular}{|ll|r|} 
& Std. Deviation & 1.36952207 \\
Most Extreme & Absolute & .065 \\
Differences & Positive & .052 \\
& Negative & -.065 \\
& & .065 \\
Test Statistic & & $.200^{\mathrm{c}, \mathrm{d}}$ \\
\hline Asymp. Sig. (2-tailed) & & \\
\hline
\end{tabular}

Berdasarkan tabel 4.7 nilai signifikansi pada uji kolmogorov-smirnov lebih besar dari 0,05 yang artinya data berdistribusi normal.

2) Uji Heterokedastisitas

Tabel Uji Heterokedastisitas

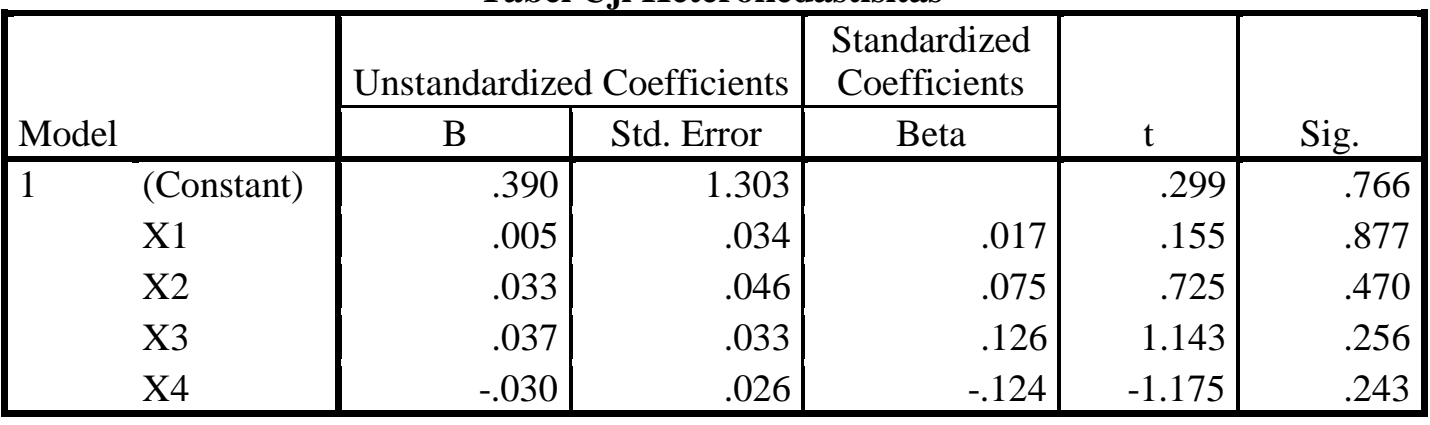

Berdasarkan Tabel diatas diperoleh nilai signifikansi untuk variabel-variabelnya tidak ada yang kurang dari 0,05 , hal ini berarti tidak terjadi heterokedastisitas.

\section{3) Uji multikolinearitas}

Tabel Uji Multikolinearitas

\begin{tabular}{|c|c|c|c|}
\hline Variabel Bebas & Tolerance & VIF & Kesimpulan \\
\hline TPA & 0,841 & 1,189 & Tidak terjadi multikolinearitas \\
\hline FBPI & 0,917 & 1,090 & Tidak terjadi multikolinearitas \\
\hline KSIA & 0,803 & 1,246 & Tidak terjadi multikolinearitas \\
\hline KSDM & 0,879 & 1,137 & Tidak terjadi multikolinearitas \\
\hline
\end{tabular}

Sumber : Hasil olahan data

Berdasarkan Tabel diatas terlihat bahwa nilai VIF dari masing-masing variabel bebas Tingkat Pemahaman Akuntansi (TPA), Fungsi Badan Pengawas Internal, dan Kualitas Sistem Informasi Akuntansi (KSIA), dan Kualitas Sumber Daya Manusia (KSDM) semuanya kurang dari 10 dan nilai tolerance berada diatas 0,1 , yang artinya tidak terjadi multikolinearitas.

\subsection{Uji Goodness of Fit}

1) Koefisien Determinasi

Tabel Koefisien Determinasi

\begin{tabular}{|l|c|r|r|r|}
\hline Model & R & R Square & $\begin{array}{c}\text { Adjusted R } \\
\text { Square }\end{array}$ & $\begin{array}{c}\text { Std. Error of } \\
\text { the Estimate }\end{array}$ \\
\hline 1 & $.685^{\mathrm{a}}$ & .469 & .448 & 1.39664 \\
\hline
\end{tabular}

Sumber: Hasil olah data

Berdasarkan tabel diatas menunjukkan nilai $\mathrm{R}$ square adjusted sebesar 0,448 yang 
artinya Kualitas Pelaporan Keuangan LPD di Kota Denpasar dapat dijelaskan sebesar 44,8\% oleh variabel Tingkat Pemahaman Akuntansi, Fungsi Badan Pengawas Internal, Kualitas Sistem Informasi Akuntansi, Kualitas Sumber Daya Manusia, sedangkan sisanya sebesar 55,2 \% dijelaskan oleh variabel lain yang tidak dimasukkan dalam model penelitian ini.

\section{2) Uji F}

ANOVA $^{\mathrm{a}}$

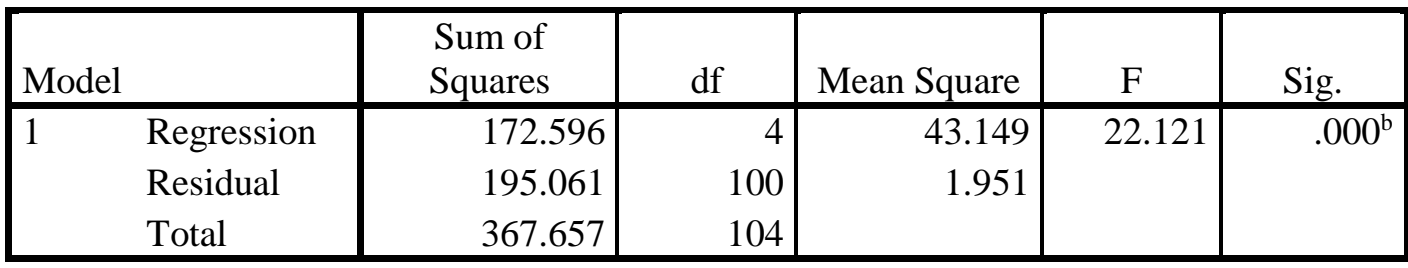

Berdasarkan tabel diatas terlihat bahwa nilai signifikansi sebesar 0,000 lebih kecil dari 0,05 , sehingga dapat disimpulkan bahwa model dalam penelitian ini fit/sesuai/tepat dengan data observasinya.

\section{3) Uji Parsial (Uji t)}

Tabel Uji t

\begin{tabular}{|c|c|c|c|c|c|c|}
\hline \multirow{2}{*}{\multicolumn{2}{|c|}{ Model }} & \multicolumn{2}{|c|}{ Unstandardized Coefficients } & $\begin{array}{c}\text { Standardized } \\
\text { Coefficients }\end{array}$ & \multirow[b]{2}{*}{$\mathrm{t}$} & \multirow[b]{2}{*}{ Sig. } \\
\hline & & $\mathrm{B}$ & Std. Error & Beta & & \\
\hline \multirow[t]{5}{*}{1} & (Constant) & 1.190 & 2.476 & & .481 & .632 \\
\hline & $\mathrm{X} 1$ & .171 & .064 & .212 & 2.667 & .009 \\
\hline & $\mathrm{X} 2$ & .543 & .088 & .470 & 6.184 & .000 \\
\hline & $\mathrm{X} 3$ & .009 & .062 & .012 & .145 & .885 \\
\hline & $\mathrm{X} 4$ & .216 & .049 & .346 & 4.448 & .000 \\
\hline
\end{tabular}

Sumber: Hasil olahan data

Berdasarkan Tabel diatas diperoleh hasil analisis sebagai berikut:

a) Karena nilai signifikansinya yang sebesar 0,009 yang nilainya lebih kecil dari 0,05 dan koefisien regresinya sebesar 0,171 maka dapat disimpulkan bahwa variabel Tingkat Pemahaman Akuntansi berpengaruh positif terhadap Kualitas Pelaporan Keuangan Akuntansi di LPD Kota Denpasar.

b) Karena nilai signifikansinya yang sebesar 0,000 yang nilainya lebih kecil dari 0,05 dan koefisien regresinya sebesar 0,543 maka dapat disimpulkan bahwa variabel Fungsi Badan Pengawas Internal berpengaruh positif terhadap Kualitas Pelaporan Keuangan Akuntansi di LPD Kota Denpasar.

c) Karena nilai signifikansinya yang sebesar 0,885 yang nilainya lebih besar dari 0,05 dan koefisien regresinya sebesar 0,009 maka dapat disimpulkan bahwa variabel Kualitas Sistem Informasi Akuntansi tidak berpengaruh terhadap Kualitas Pelaporan Keuangan 
Akuntansi di LPD Kota Denpasar.

d) Karena nilai signifikansinya yang sebesar 0,000 yang nilainya lebih kecil dari 0,05 dan koefisien regresinya sebesar 0,216 maka dapat disimpulkan bahwa variabel Kualitas Sumber Daya Manusia berpengaruh positif terhadap Kualitas Pelaporan Keuangan Akuntansi di LPD Kota Denpasar.

\section{PEMBAHASAN}

1. Tingkat pemahaman akuntansi berpengaruh positif terhadap kualitas pelaporan keuangan akuntansi di LPD Kota Denpasar. Hal ini berarti semakin memahami tentang akuntansi maka laporan keuangan yang dihasilkan akan semakin berkualitas. Bila pemahaman tentang akuntansi kurang, maka laporan keuangan yang dihasilkan akan kurang berkualitas, ini disebabkan karena kurangnya pemahaman akan akuntansi maka tidak akan mampu menyusun laporan keuangan yang sesuai dengan peraturan yang berlaku umum.

2. Fungsi badan pengawas internal berpengaruh positif terhadap kualitas pelaporan keuangan akuntansi di LPD Kota Denpasar. Fungsi badan pengawas sangat mempengaruhi kualitas pelaporan keuangan, karena apabila fungsi badan pengawas dijalankan dengan baik maka akan menghasilkan laporan keuangan yang berkualitas, begitu pula sebaliknya bila fungsi badan pengawas tidak berjalan maka laporan keuangan yang dihasilkan tidak berkualitas atau tidak sesuai dengan yang diharapkan.

3. Kualitas sistem informasi akuntansi tidak berpengaruh terhadap kualitas pelaporan keuangan akuntansi di LPD Kota Denpasar. Hal ini berrati bahwa kualitas sistem informasi tidak ada pengaruhnya terhadap kualitas pelaporan keuangan, walaupun kualitas sistem informasi bagus atau tidak, hal tersebut tidak akan mempengaruhi kualitas dari lporan keuangan yng dihasilkan.

4. Kualitas Sumber Daya Manusia berpengaruh positif terhadap Kualitas Pelaporan Keuangan Akuntansi di LPD Kota Denpasar. Semakin berkualitas sumber daya yang digunakan maka akan semakin berkualitas laporan keuangan yang dihasilkan. Bila sumber daya manusia yang digunakan dalam penyusunan laporan keuangan kurang berkompeten, maka pelaporan keuangan kurang berkualitas.

\section{KESIMPULAN}

Berdasarkan analisis data dari kuesioner yang disebar ke 35 LPD di Kota Denpasar diperoleh kesimpulan sebagai berikut: Variabel Tingkat Pemahaman Akuntansi berpengaruh positif terhadap Kualitas Pelaporan Keuangan Akuntansi di LPD Kota Denpasar.Variabel Fungsi Badan Pengawas Internal berpengaruh positif terhadap Kualitas Pelaporan Keuangan Akuntansi di LPD Kota Denpasar. Variabel Kualitas Sistem Informasi Akuntansi tidak berpengaruh terhadap Kualitas Pelaporan Keuangan Akuntansi di LPD Kota Denpasar.Variabel Kualitas Sumber Daya Manusia berpengaruh positif terhadap Kualitas Pelaporan Keuangan Akuntansi di LPD Kota Denpasar.

\section{SARAN}

Hasil penelitian ini dapat dijadikan dasar atau acuan bagi pemerintah kota Denpasar dalam penilaian pelaporan kualitas laporan keuangan LPD yang ada di kota Denpasar. Bagi LPD, hasil penelitian ini memberi masukan bagi pembuat laporan keuangan agar bisa memperhatikan faktor-faktor yang berpengaruh untuk meningkatkan kualitas pelaporan keuangan. Untuk penelitian selanjutnya dapat menambahkan variabel bebas lain seperti idealisme, pengalaman auditor yang mungkin berpengaruh terhadap kualitas pelaporan keuangan di LPD Kota Denpasar 


\section{UCAPAN TERIMA KASIH}

Ucapan terima kasih kami sampaikan kepada seluruh staf LPD yang ada di Kota Denpasar, yang telah meluangkan waktu untuk pengisian kuisoner terkait penelitian ini.

\section{DAFTAR PUSTAKA}

Aniftahudin. 2016. Pengaruh Pemahaman Akuntansi, Sistem Akuntansi Keuangan Pemerintah Daerah Dan Teknologi Informasi Terhadap Kualitas Laporan Keuangan Pemerintah Daerah. Jom Fekon, vol 3 No 1

Ghozali, Imam. 2016. Aplikasi Analisis Multivariate dengan Program IBM SPSS 20. Edisi Kelima. Semarang: Universitas Diponegoro.

Hertati Lesi. 2015. Competensi of human resources, the benefit of information technology on value of financial reporting in indonesia. Research journal of finance and accounting, Vol 6, No. 8

Jogiyanto. 2008. Sistem Informasi Keperilakuan. Yogyakarta: Andi Offset.

Juwita Rukmi. 2013. Pengaruh Implementasi Standar Akuntansi Pemerintahan Dan Sistem Informasi Akuntansiterhadap Kualitas Laporan Keuangan. Trikonomika, Vol 12 No.2

Komite Standar Akuntansi Pemerintahan (2005). Peraturan Pemerintah Nomor 24 Tahun 2005 tentang Standar Akuntansi Pemerintahan

Lasmara Freddie dan Rahayu Sri. 2016. Pengaruh Kompetensi Sumber Daya Manusia, Perangkat Pendukung Dan Peran Auditor Internal Terhadap Kualitas Laporan Keuangan Pemerintah Daerah Kabupaten Kerinci. Jurnal Perspektif Pembiayaan dan Pengembangan Daerah Vol 3 No.4

Peraturan Pemerintah Nomor 24 Tahun 2005 tentang Standar Akuntansi Pemerintahan.

Peraturan Pemerintah Nomor 71 Tahun 2010, tentang Standar Akuntansi Pemerintah.

Putra I Gede Cahyadi dan Gunadi I gusti Ngurah. 2017. Etika Kepemimpinan Dan Fungsi Badan Pengawas Pengaruhnya Terhadap Kualitas Pelaporan Keuangan Lembaga Perkreditan Desa. Jurnal Ilmu Manajemen Vol 7. No. 2

Ramdany. 2015. Influence The Quality Of Accounting Information System And The Effectiveness Of Internal Control On Financial Reporting Quality. Reseach Journal Of Finance And Accounting. Vol 6, No.6

Robbins, Stephen, 2006, "Perilaku Organisasi”, Prentice Hall, edisi kesepuluh Sabardini, 2006, "Peningkatan Kinerja Melalui Perilaku Kerja Berdasarkan Kecerdasan Emosional", Telaah Bisnis, Vol.7, No.1. 
Rosdiani, Hayyuning Tyas. 2011. Pengaruh Sistem Pengendalian Internal Audit Laporan Keuangan dan Penerapan Good Corporate

Sugiyono. 2017. Metode Penelitian Bisnis. Cetakan 11. Bandung: CV Alfabeta.

Susanto, Azhar. 2013. Sistem Informasi Akuntansi. Bandung: Lingga Jaya.

Tawaqal Irzal dan Suparno. 2017. Pengaruh Penerapan Sistem Informasi Akuntansi, Sistem Pengendalian Internal, Dan Kompetensi Sumber Daya Manusia Terhadap Kualitas Laporan Keuangan Satuan Kerja Perangkat Daerah Di Pemerintah Kota Banda Aceh. Jurnal Ilmiah Mahasiswa Ekonomi Akuntansi Vol 2, No. 4

Yuliani, Syafrida. 2010. Pengaruh Pemahaman Akuntansi, Pemanfaatan Sistem Informasi Akuntansi Keuangan Daerah Dan Peran Internal Audit Terhadap Kualitas Laporan Keungan Pemerintah Daerah (Studi Empiris Pada Pemerintah Kota Banda Aceh). Jurnal telaah dan riset akuntansi Vol 3 No 2 hal 206-220. 